\title{
TEATR SŁOWA. \\ WOKÓŁ KONCEPCJI JULIUSZA OSTERWY ORAZ MIECZYSŁAWA KOTLARCZYKA I KAROLA WOJTYŁY
}

Celem artykułu będzie próba skonfrontowania dwóch teorii teatru słowa Juliusza Osterwy oraz Mieczysława Kotlarczyka i Karola Wojtyły, mieszczących się wokół zagadnienia ,praelementów teatru”. Zjawisko to wydaje się o tyle interesujące, że zdaniem Jana Ciechowicza stanowi podstawę „światopoglądu teatralnego" (Ciechowicz, „Z Wadowic w świat” 13) Wojtyły, zaś w ocenie Janusza Pasierba „korzenie metodologiczne" (Pasierb 592) jego poetyki i dramaturgii. Analiza zjawiska obejmować będzie kanoniczne teksty obu twórców: listy i zapiski prywatne Osterwy zgromadzone w tomie Przez teatr - poza teatr (Osterwa) oraz korespondencję, publicystykę teatralną i wypowiedzi teoretycznoteatralne Wojtyły opublikowane w wyborze Poezje i dramaty (Wojtyła, Poezje i dramaty), i przypomniane niedawno w jego Dziełach literackich i teatralnych (Dzieła literackie i teatralne 1). Słowo rozumiane jako ,praelement teatru", a zarazem jako siła żywa i działająca, stanowić będzie - w moim rozumieniu - podstawowy wyznacznik myślenia teatrem Karola Wojtyły.

\section{WOJTYŁA I OSTERWA}

Na wstępie warto przypomnieć okoliczności fascynacji Wojtyły Osterwą i jego koncepcją teatru słowa. Przywołując wcześniejsze ustalenia Ciechowicza („Światopogląd teatralny Karola Wojtyły" 114-128) oraz Jacka Popiela (253-278) należy

Dr hab. AnNA SoBIECKA, prof. AP - Zakład Antropologii Kultury i Badań Kaszubsko-Pomorskich, Katedra Filologii Polskiej w Instytucie Filologii AP; adres do korespondencji: Akademia Pomorska, ul. Arciszewskiego 22a, 76-200 Słupsk; e-mail: anna.sobiecka@apsl.edu.pl. ORCID: http://orcid.org/ 0000-0001-5155-0393. 
odnotować, że pierwszy kontakt z twórcą Reduty miał miejsce w ramach wyjazdów wadowickiego Teatru Szkolnego do Krakowa na przedstawienia Teatru im. Juliusza Słowackiego, w którym Osterwa od września 1932 roku pełnił funkcję dyrektora. Młodzież oglądała klasykę polską i obcą, w tym: Fircyka w zalotach, Fantazego, Horsztyńskiego, Lillę Wenedę, Kordiana, Zemstę, Księcia Niezłomnego, Cyda i Wesele. W 1937 roku Wojtyła poznaje Kotlarczyka, późniejszego twórcę Teatru Rapsodycznego, a rok później przenosi się z ojcem do Krakowa. Tam podejmuje studia polonistyczne na Uniwersytecie Jagiellońskim, żywo uczestniczy w działaniach sekcji literackiej Koła Polonistów, a w 1939 roku rozpoczyna współpracę ze „Studiem 39”, szkołą dramatyczną prowadzoną przez Krakowską Konfraternię Teatralną. Wybuch drugiej wojny światowej zmienia charakter działań teatralnych podejmowanych przez młodych aktorów. Rozpoczyna się okres tajnego czytania „z podziałem na role" (Popiel 263) literatury polskiej oraz konspiracyjnych spotkań w mieszkaniach prywatnych Juliusza Kydryńskiego, Tadeusza Kudlińskiego, jak również u Osterwy, na Basztowej 1 (Świątkowska 88). Podczas jednego z takich spotkań, w marcu 1940 roku, Wojtyła poznaje aktora. W liście do Kotlarczyka wspominał:

Poznałem Juliusza Osterwę. Zapoznał mnie z nim Kydryński, wiesz, ten kolega z polonistyki. Byliśmy już u niego dwa razy. Jest dla nas bardzo uprzejmy, traktuje bardzo serdecznie i zaprasza. Mówiłem o Tobie. ... Sam on pracuje bardzo dużo. Mówi nam: „pojęcie teatr już nam właściwie nie wystarcza, tu trzeba czegoś więcej”. - „Aktor to nie jest błazen, to działacz pełniący swoje posłannictwo". - W każdym razie to człowiek dużej, bardzo dużej miary. - A, co nade wszystko ujmuje, to ten ogrom pracy, pracy i jeszcze raz pracy. Obecnie twierdzi on, że zajmuje go język. Widzi go być nadto zachwaszczonym wyrażeniami obcymi, tak że się zatraca zdrowy rdzeń wśród tego. - Pokazywał nam swoje notatki. Kalendarz teatralny, tak jak i myśmy to myśleli: Lilla Weneda - maj, Balladyna - lipiec, Sułkowski - wrzesień, Wesele - październik, Dziady - listopad itd. (Dzieła literackie i teatralne 1: 355)

Od tego momentu Wojtyła pozostaje w kręgu oddziaływania Osterwy. Spotkania w domu Kydryńskich, Szkockich i u Kudlińskiego nie ustają, coraz częściej przybierają formę próby teatralnej. W sierpniu 1940 roku do grupy dołącza Danuta Michałowska i rozpoczynają się czytania sztuki Stefana Żeromskiego Uciekła mi przepióreczka. Pod kierunkiem Osterwy młodzi aktorzy przygotowują II akt Przepióreczki, w którym występują trzy osoby: Kydryński (Przełęcki), Wojtyła (Smugoń), Michałowska (Dorota). Przedstawienie jest prezentowane we wrześniu 1940 roku w warunkach konspiracyjnych, choć prawdopodobnie bez udziału samego Osterwy, który w tym czasie przebywał w Ściborzycach (Świątkowska 89). Współpraca trwa dalej. Regularnie odbywają się „posiedzenia”, zwane też „tygodniówkami”. Twórca Reduty, przygotowując się do realizacji Hamleta Williama Szekspira, proponuje młodym adeptom sztuki scenicznej rozpisanie ról Hamleta (Wojtyła), Horacego 
(Kydryński), Klaudiusza (Kudliński) i Ofelii (Michałowska) własnymi słowami (Popiel 267). Osterwa proponuje Wojtyle samodzielny przekład Edypa.

W tym samym czasie pojawiają się pierwsze sygnały krytycznego spojrzenia na program Osterwy, który intensywnie przygotowuje się do objęcia dyrekcji teatru krakowskiego po zakończeniu wojny. Dłuższy ustęp listu do Kotlarczyka datowany na miesiące kwiecień/lato 1940 roku tłumaczy istotę różnic w podejściu do definiowania zadań teatru i jego repertuaru:

Co się tyczy Juliusza, to owszem. Bywamy u niego co tydzień. Jesteśmy nawet poniekąd zadomowieni. On tutaj pracuje (trzeba mu to przyznać, że jest człowiekiem wielkiej pracy) - otóż pracuje nad niektórymi utworami ze swej linii repertuarowej. Całość tej linii jest mniej więcej następująca: Oresteja, Edyp, Antygona - Lilla Weneda, - Sen nocy letniej - Balladyna - Dziady, Nie-Boska - Wesele - Hamlet - Wyzwolenie. Otóż chodzi mu o przekłady. Zgadzamy się chyba w tem (sic), że przekłady Morawskiego i Butrymowicza nie tylko, że są scenicznie ciężkie, ale w ogóle nawet do zgryzienia twarde. Otóż Juliusz powiada: „chcę, żeby to mogły słuchać z pełnym zrozumieniem nawet kucharki" (kładzie akcent na tym ostatnim) - i przekłada sam, w sposób sceniczny. Tak przełożył Antygonę, obecnie przekłada Hamleta (monologi Wysp.[iańskiego]). Nam polecił pracować nad innemi (sic). Już dokonałem tej „osterwiańskiej” rewizji Edypa. Przełożyłem Edypa na język ludzki. Juliusz był b.[ardzo] zadowolony, ale dalej twierdzi, że to jeszcze nie jest sceniczne. Mówi zresztą, że sceny trzeba się uczyć. No, niewątpliwie! (Nie przejmuj się tym niescenicznym rezultatem mojego przekładu: Osterwa twierdzi to samo o przekładach Kasprowicza). W ogóle nas polubił, nawet bardzo. Jesteśmy u niego co tydzień (ja nierzadko się w „tygodniówkach” opuszczam). (Dzieła literackie i teatralne 1: 359-360)

Wojtyła postrzega Osterwę jako sprawnego organizatora i dyrektora teatru, jako osobę kompetentną w zakresie ustaleń repertuarowych i kadrowych, wreszcie jako nietuzinkowego aktora, którego siłą ekspresji pozostaje słowo wypowiadane na scenie:

W całości oceniając jego myśl teatralną, widzę, że ma znakomicie przemyślane i przepracowane szczegóły (czasem aż za dobrze... - czasem dziwaczy nieco), ale bez komplementów, Ty mi bardziej odpowiadasz. Na Osterwie bądź co bądź ciąży atawistycznie teatr... i niestety... Warszawa, my jesteśmy, że się tak wyrażę - prymitywniejsi. Chociaż ma czasem pomysły kapitalne. Poza tem... my jesteśmy bardziej jak bracia, on bądź co bądź ojczaszek (bardzo serdeczny, ale ojczaszek). Zresztą powiadam Ci: polubił nas. Mówi, że chciałby nas mieć blisko, b.[ardzo] blisko siebie. - Aha, co najważniejsze - zdaje mi się, że Ty - mój Kochany Amatorze i Dyrektorze - zdaje mi się - podejrzewam - i wyżej mierzysz i dalej patrzysz, a o ile na razie jeszcze nie - to czuję, że dalej spojrzysz. To tyle o Juliuszu, pierwszy raz nieco więcej. No, teraz już przecie zdołałem coś wysondować po tylu ,posiedzeniach”. Ale on fantastycznie mówi! Aktor to z niego musi być! No i dyrektor! Co tu gadać... ale... (nic nie jest bez ale...). (Dzieła literackie i teatralne 1: 360)

W miarę upływu kolejnych miesięcy wojennych, początkowa fascynacja Osterwą przeradza się w bardziej krytyczne postrzeganie jego osobowości twórczej. Jak pisze Wojtyła - „Osterwianiz” ustępuje miejsca fascynacjom koncepcjami Kotlarczyka, z którym łączy Wojtyłę coraz bardziej zażyła przyjaźń oraz wspólnota poglądów: 
Osterwianizm został chwilowo przerwany. Dyrektor wyjechał. Zresztą nie imponuje mi znów tak nade wszystko. Ja zasadniczo jestem bardziej przywiązany do ludzi o tajemniczym wnętrzu, o wielkim wnętrzu. Nie znaczy to, ażeby Dyrektor go nie posiadał. Ale, wierzcie mi, trochę mam wrodzonej niechęci do tych murowanych już słów. Może dlatego, że jakoś nie możemy mimo wszystko mówić na jednym poziomie. W każdym razie, silnych tam więzów nie czuję, nie, wcale nie. (Dzieła literackie i teatralne 1: 363)

Nie można zapominać, że w tym samym czasie Wojtyła zaczyna pisać teksty dramatyczne (powstaje Hiob i Jeremiasz), podejmuje fizyczną pracę jako robotnik w Zakładach Chemicznych Solvay w Borku Fałęckim (wrzesień 1940), umiera mu ojciec (luty 1941), wreszcie kształtuje się decyzja o porzuceniu teatru i aktorstwa, i wyborze innej drogi życiowej. Początek 1941 roku to także ostatnie spotkania teatralne z Osterwą, który młodym aktorom ze „Studia 39” powierza lekturę misterium Oskara Miłosza Miguel Mañara. W lipcu do Krakowa przyjeżdża Kotlarczyk i już wkrótce powstaje Teatr Rapsodyczny, a wraz z nim kolejne role „rapsodyczne” Wojtyły: monolog Bolesława Śmiałego z Króla-Ducha (1941), apostrofa do Ludwiki Śniadeckiej z Beniowskiego (1942), wybrane Hymny Kasprowicza (1942), rola Jaśka w Godzinie Wyspiańskiego (1942), partie księdza Robaka w Panu Tadeuszu (1942) oraz tytułowa rola w Samuelu Zborowskim (1943) (Popiel 273-279) ${ }^{1}$. Jak przekonuje Popiel, Wojtyła po odejściu z Teatru Rapsodycznego, co następuje w sierpniu 1944 roku, w momencie, gdy wstępuje do Seminarium Metropolitalnego (miesiąc później przyjmuje niższe święcenia kapłańskie), nigdy nie przestaje interesować się dokonaniami zespołu oraz losami najbliższych przyjaciół.

\section{TEATR I SŁOWO}

W 1952 roku Wojtyła jako Piotr Jasień publikuje na łamach Tygodnika Powszechnego recenzję zatytułowaną O teatrze słowa (Wojtyła, Poezje i dramaty 435-442). Pięć lat później, jako Andrzej Jawień, powraca do rozważań dotyczących stylu rapsodycznego w artykule Dramat stowa i gestu (Poezje i dramaty 443-447). Badacze twórczości Wojtyły pozostają zgodni, że oba teksty, będące w swym zamiarze analizami przedstawień Teatru Rapsodycznego, pozostają jednymi z najbardziej trafnych komentarzy stylu rapsodycznego ${ }^{2}$. Jego podstawowym wyznacznikiem jest słowo,

\footnotetext{
${ }^{1}$ Popiel wyraźnie rozgranicza potwierdzone role grane przez Wojtyłę w przedstawieniach rapsodyków oraz te, co do których trudno jest jednoznacznie ustalić udział i wkład Wojtyły (zob. Popiel 273-279).

${ }^{2}$ O teatrze słowa to recenzja Aktorów w Elzynorze według Szekspira (premiera 5 grudnia 1951), Dramat stowa $i$ gestu to próba podsumowania działalności Teatru Rapsodycznego w momencie jego reaktywowania w 1957 roku. Dwa kolejne teksty Wojtyły poświęcone Teatrowi Rapsodycznemu to:
} 
traktowane przez Wojtyłę jako „praelement teatru”, co wyjaśnia szczegółowo: „,[...] może też słowo wystąpić jako «pieśń» - wyodrębnione, samodzielne, przeznaczone tylko do zawierania myśli i jej głoszenia, do ogarniania pewnej wizji umysłowej i jej przekazywania" (Poezje i dramaty 436). Słowo tak pojmowane staje się ,słowem rapsodycznym", a teatr przyjmujący ową koncepcję słowa - „teatrem rapsodycznym”. Jego wyznacznikami pozostają: , intelektualizm rapsodyczny”, rozumiany jako uznanie słowa za nośnik treści, prawd, idei i struktur, a nie jedynie wyznacznik akcji oraz przedstawienia definiowane jako wydarzenia afabularne, problemowe, ideowe. W zakresie strony formalnej stylu rapsodycznego (teatru słowa) ważne jest słowo „wyodrębnione jako wyraz myśli, nie jako współczynnik działania, słowo głoszone, idea głoszona żywym słowem" (Poezje i dramaty 438). Słowu wypowiadanemu na scenie podporządkowane zostają wszystkie płaszczyzny przedstawienia: jego wrażenia słuchowe, wzrokowe, muzyka i dekoracje, statyka i dynamika obrazu teatralnego, a także sztuka aktorska, a wraz z nią gestykulacja (oszczędna, prosta, rytmiczna), mimika i ruch sceniczny (najlepiej taneczny, baletowy, nie-naturalistyczny). Aktor w stylu rapsodycznym ,gra”, „niesie” problem, nie odtwarza postaci, nie staje się nią w znaczeniu scenicznym, ,przestaje mówić jako dana postać, zaczyna mówić o niej" (Poezje i dramaty 438). Ważnym elementem stylu rapsodycznego są także: muzyka, podporządkowana ,potędze” zrytmizowanego słowa, ,[...] które przestaje być tylko środkiem, a staje się samoistnym żywiołem" (Poezje i dramaty 439), oraz plastyka, będąca - podobnie jak słowo - czynnikiem koncentracyjnym przedstawienia, oszczędnym, choć różnicującym przestrzeń sceniczną, uwolnioną od zbędnych rekwizytów.

Związek między sposobem rozumienia słowa (teatru słowa) w Teatrze Rapsodycznym a koncepcją Osterwy wydaje się oczywisty. W stosunku do stylu rapsodycznego Ciechowicz nie zawahał się użyć określenia „Reduta słowa”, wyraźnie wskazując na analogie zachodzące między zjawiskami (Ciechowicz, „Reduta słowa” 387). Na czym polega jednak owe podobieństwo czy raczej zbieżność myślenia o słowie jako praelemencie teatru. W okresie wojny i okupacji Osterwa nie tylko poznaje koncepcję stylu rapsodycznego, ale także doświadcza głębokiej przemiany religijnej. Przygotowując się do objęcia teatru krakowskiego po wojnie, uczy kleryków wymowy w seminariach duchownych, recytuje konspiracyjnie w domach przyjaciół i znajomych, czyta i studiuje teksty pisarzy katolickich oraz filozofów idealistycznych, w tym, m.in.: Wincentego Lutosławskiego, Augusta Cieszkowskiego i Bronisława Trentowskiego. Przygotowuje oryginalne projekty powojennej organizacji

„Rapsody Tysiąclecia”. Tygodnik Powszechny, nr 3, 1958 oraz „Dziady i dwudziestolecie”. Tygodnik Powszechny, nr 40, 1961. 
życia teatralnego, ale przede wszystkim projekty bractw czy raczej stowarzyszeń teatralno-religijnych określanych mianem Dal i Genezja (Osiński 139-163). Rozważa możliwości wprowadzenia słowa - określanego jako Żywosłowie - w materię scenicznego i pozascenicznego życia ${ }^{3}$. W efekcie przemian dokonujących się w nim samym, ale także w sposobie definiowania sztuki teatru powstaje zamysł sztuki żywego, czyli działającego słowa:

Nam chodzi o wyzwolenie się z tych usłużnych czynności - w publicznych domach - a poświęcenie się uczczeniu Bożego Piękna - przez Służbę Społeczeństwu Zespolonemu. Nie chcemy być teatrem, tyjatrem [sic], ale wróciwszy do przeznaczeń teatronu [sic] greckiego pójść dalej, wzbić się wyżej. Poświęcić się Słowu, które było na Początku i wielbić Piękno tego Słowa. (Osterwa 347)

W koncepcji Osterwy nowy teatr ma stać się Słowopięknią, czyli miejscem „żywego istnienia i bezpośredniego działania Słowa - Piękna" (Osterwa 344), scena Spełnią, czyli miejscem ,pełnią Słowa Dobrego - prawdziwego, pięknego. Prawdy - Dobra - Piękna" (345), zaś aktorzy - Spełnikami, to znaczy, ludźmi spełniającymi swoje posłannictwo dzięki sztuce aktorskiej, oddającymi granym przez siebie postaciom „swoje żywe ciało, swoją myśl, czucie, wolę - słowem: swoją duszę" (345). Nowy teatr czyli Żywosłownia lub inaczej Dal ma stanowić zespoloną rzeszę współpracowników Słowopiękni.

Tak samo mocno, jak w potrzebę autentycznej przemiany teatru, wierzył Osterwa w zbawczą moc Słowa zawartego w Piśmie Świętym:

Pragniemy temu Słowu - zaklętemu w Pismo - dać nasze życie, dać nasze ciało, naszą człowieczą myśl, czucie, wolę i przez to pośrednictwo uduchowić to słowo, aby działało na społeczeństwo pol[skie] i je zachwycało do życia narod[owego] - i je uświadomiało w Ofierze. Naszą pracę uważamy za posłaństwo - i za spełnienie Ofiary dla Piękna Bożego. (Osterwa 274)

Kreacyjna moc słowa, wedle Osterwy mogącego działać i przemieniać, pozostaje zatem zbieżna z koncepcją Kotlarczyka, w której ,przeznaczeniem teatru jest pomagać ludzkości w jej wielowiekowej wędrówce ku Bogu, rzucać człowieka w sfery ponadmaterialnych płaszczyzn” (cyt. za: Ciechowicz, „Reduta słowa” 389). Prymat Słowa (pisanego wielką literą), ale także słowa żywego, ,autonomicznego” i niejako „autokratycznego” w strukturze tekstu oraz spektaklu (Kotlarczyk, „Co to jest teatr Rapsodyczny?" 12), potwierdza manifest Teatru Rapsodycznego Teatr Nasz:

\footnotetext{
${ }^{3}$ Podobnie do tych kwestii odnosi się D. Kosiński (zob. Kosiński, Dariusz. „Żywosłowie”. Performer, nr 3, 2011, www.grotowski.net/performer/performer-3/zywoslowie, [przedruk jako:] „Żywosłowie - zapomniane marzenie porzuconego patrona". Zeszyty Naukowe PWST im. Ludwika Solskiego w Krakowie, $\mathrm{nr}$ 4, 2012, ss. 46-52).
} 
Jak dotąd, naczelnym zadaniem i najistotniejszym rysem całej naszej działalności jest kult Słowa, żywego i czystego, w teatrze autonomicznego, a nawet autokratycznego, tzn. absolutnie niezależnego od konwencjonalnych akcesoriów teatru tradycjonalistycznego. Jest to teatr bez kurtyny i sceny, bez dekoracji, kostiumów i masek. Teatr bardziej za to skupiony, bardziej uduchowiony, bardziej wnętrza. Jest to teatr Słowa żywego i czystego!... ale jeszcze niepełnego! (Kotlarczyk, „Teatr Nasz” 4)

Co więcej, słowo traktowane jest przez Kotlarczyka jako element nie tylko artyzmu z znaczeniu pewnej doskonałości, ale także jako element uduchowiony, mogący sięgać Absolutu:

Słowo potrafi wyrazić nadto jeszcze i to wszystko, czego już żadna inna sztuka nie jest w stanie wyrazić: Słowo zdolne jest sięgać w strefę niedostępną w żadnym wypadku innym sztukom; w strefę czystych, abstrakcyjnych pojęć, w strefę czystych myśli; w strefę czystej idei. Słowo najwyższa emanacja duszy, zdolne wyrazić najwyższe szczyty duszy. (Teatr Rapsodyczny, 36-37)

Proces działania słowem w teatrze zakładał także Wojtyła, traktując słowo nie tylko jako podstawowy element sztuki dramatycznej, ale również jako „zalążek działania” (Poezje i dramaty 444), „zaczyn dramatu”, ,ferment, przez który przechodzą ludzkie czyny, skąd czerpią swoją właściwą dynamikę" (Poezje i dramaty 443). Tak pojmowane słowo Wojtyła łączył z funkcją teatru mogącego nie tylko oddziaływać na człowieka, ale i go przemieniać.

\section{TEATR I ETYKA}

Kwestią równie istotną w myśleniu Wojtyły o teatrze pozostaje jego siła etyczna. Sztuka, która nie jest „li tylko prawdą realistyczną, albo li tylko zabawą, ale nade wszystko jest nadbudową, jest spojrzeniem wprzód i wzwyż, jest towarzyszką religii i przewodniczką na drodze ku Bogu; ma wymiar romantycznej tęczy: od ziemi i od serca człowieczego ku Nieskończonemu - bo wtedy stają przed nią horyzonty przeogromne, metafizyczne i anielskie" (Dzieła literackie i teatralne 1: 350) - jak pisał w liście do Kotlarczyka - odzwierciedlała sposób myślenia o teatrze jako o jednej z wielu dróg prowadzących do Prawdy. W artykule $O$ teatrze stowa, uzasadniając sięganie przez Teatr Rapsodyczny po dramaturgię Szekspira, Wojtyła przekonuje, że „wielka siła etyczna teatru” wiąże się ściśle z jego repertuarem oraz „posłannictwem”, które rozumiane jest w odniesieniu do znanego sformułowania Stratfordczyka: „Przeznaczeniem jego, jak dawniej, tak i teraz, było i jest służyć za zwierciadło i wzór naturze i życiu, dawać prawdę dobra i zła w świecie, kształtować ducha czasu, ducha postępu, i być jego pięknem" (Poezje i dramaty 435). Przykładem spektaklu rapsodyków traktującego o istocie posłannictwa artystycznego i etycznego 
teatru jest, zdaniem Wojtyły, spektakl o Aktorach w Elzynorze, w którym naczelną postacią pozostaje Hamlet, bohater rozdarty między dwoma sprzecznościami: tym, co w nim ludzkie i człowiecze (dramat uczucia), oraz tym, co stanowi o sensie jego istnienia w ogóle (dramat sumienia i powinności).

Równie ważną kwestią związaną z etyką teatru jest - w ocenie Wojtyły - związek między słowem w teatrze (słowem w znaczeniu rapsodycznym) a słowem pojmowanym jako zalążek działania. Supremacja słowa w teatrze powoduje bowiem zwrócenie uwagi widza-słuchacza na wewnętrzną, duchową istotę spektaklu czy też teatru w ogóle. Jego rola katartyczna pozwala docierać do „wnętrza ludzkiego działania, do samych spoideł ludzkiego ruchu" (Poezje i dramaty 444). Ma więc moc kreacyjną, w czym Wojtyła zgadzał się w pełni z Kotlarczykiem ${ }^{4}$.

Etyka, a raczej utopijna w swym zamyśle religia teatru, pozostawała także w kręgu zainteresowań Osterwy ${ }^{5}$. Zbawcza moc słowa miała zarazem potęgę sprawczą, kreacyjną. Oznaczała przemianę, ,,przeistoczenie”, dokonujące się w człowieku za sprawą słowa żywego i natchnionego, co zdają się potwierdzać notatki:

Czwarty stopień zdolności spełniczej
to zdolność służenia - Istotom wyższym
i wyrażania ich woli - przez swoje usta
w oznace - posła, zastępcy, wyręczyciela -
to już oznaka kapłańska.
Nie udaję wyższej istoty - ani ją naśladuję - ani jestem tą istotą - jestem posłany przez istotę,
powołany przez nią na pośrednika między nią a światem.
Tak więc można udawać anioła, jego postać, jego głos.
Można przeżywać to, czym anioł żył, żyje i żyć, jak anioł żyje.
Można się chcieć przeistoczyć w anioła i mówić jak anioł, i można przemawiać w imieniu anioła. (Osterwa 201-202) ${ }^{6}$

W późnym okresie twórczości, który autorzy wyboru pism Przez teatr - poza teatr określają mianem Czasu Przejścia i Czasu Genezjusza, funkcje sztuki teatru, inaczej Słowopełni, definiował Osterwa analogicznie do przytoczonych już wcześniej słów Wojtyły. Patronował im Szekspir: „Teatru przeznaczeniem było i jest: służyć niejako za zwierciadło właściwości ludzkiej, pokazywać cnocie własne jej rysy, złości żywy jej obraz, a przez pięknotę - światu ukazywać jego postać - a duchowi wieku jego

\footnotetext{
${ }^{4}$ Podobnie kwestie te rozpatruje Katarzyna Flader (zob. Flader, Promieniowanie rapsodyzmu 11, 30, 119).

${ }^{5} \mathrm{Z}$ utopijnym charakterem koncepcji Osterwy z okresu wojny i okupacji zgadzają się także autorzy wyboru jego pism (zob. Osterwa, Przez teatr - poza teatr 36-53).

${ }^{6}$ Osterwa wyróżniał cztery stopnie rozwoju artystycznego: naśladowanie (przez udawanie), przeżywanie (przejęcie się postacią), przeistoczenie oraz obrzędowość (zob. Osterwa, Przez teatr - poza teatr 196- 200).
} 
piękno" (Osterwa 224). Sam teatr określał jako Słowopięknię, czyli miejsce żywego istnienia i bezpośredniego dzialania Słowa - Piękna (344).

Bardzo szczegółowe, aczkolwiek utopijne, plany odnowy sztuki teatru pozostały jedynie w sferze marzeń Osterwy. Aktor, który marzył o roli Hamleta i nigdy jej nie zagrał $^{7}$, nie wprowadził także w życie koncepcji związanych ze stowarzyszeniem teatralno-religijnym zwanym Dalą oraz kolejnym jego poziomem wtajemniczenia - Genezją, w ramach której praca Genezjan była utożsamiana ze służbą Bogu (173 i 335). „Po to żyjemy, żyć będziemy, byśmy Boga po-znali, po-kochali Go i JEMU Służyli" (354) - notował w Raptularzu. Plany pokrzyżowała śmiertelna choroba Osterwy, który zmarł w maju 1947 roku.

Zanim to jednak nastąpiło, w Raptularzu z października 1946 roku pojawił się arcyciekawy wpis dotyczący Teatru Rapsodycznego i niezwykłego sposobu rozumienia przez Osterwę koncepcji słowa rapsodycznego:

Teatr Rapsodyczny jest niezwykły.

Ani dotąd w Polsce, ani za granicą nie widziało się czegoś podobnego.

Teatr - powiadają - to ,akcja” - działanie - ruch.

Tu ruch jest ograniczony do „najmniejszości”.

Tu się tylko służy Słowu - uskrzydlonemu - wybranemu.

Tu się widzi Słowo i słucha szelestu jego skrzydeł.

Patrząc i słuchając, odpoczywa się. ...

Tu się czuje, jak duch wytłumaczą. (367)

Komentarz Osterwy potwierdza zatem podobny sposób rozumienia znaczenia słowa żywego, wypowiadanego, „uskrzydlonego”, ale i mogącego działać, przemieniać. Ta najistotniejsza, jak się wydaje w rozumieniu Osterwy, funkcja słowa oznaczała analogiczny sposób rozumienia funkcji sztuki teatru, ponieważ:

[...] można by teatr - nazwać Słow o pełni ą - czyli miejscem Słow a pełne go - bo nie tylko pisanego, nie tylko wygłaszanego - ale i pełnie pełnionego. ... Kto by chciał nadal działać na S c e ni e - na drodze przez labirynt zwany te atr - niech działa - ... Wkraczając na nowa drogę ku miejscom - Wielkiej Przemiany -. (178)

Wykazane podobieństwo między teatrem słowa Mieczysława Kotlarczyka i Karola Wojtyły oraz Juliusza Osterwy sprowadza się do dwóch fundamentalnych analogii -

\footnotetext{
${ }^{7}$ Pisałam o tym w odrębnym artykule (zob. Sobiecka, „Kudliński i Osterwa. Sprawa Hamleta”, 139-151).
} 
sposobów pojmowania funkcji słowa żywego i działającego oraz funkcji teatru jako sztuki słowa żywego i mogącego oddziaływać oraz przemieniać. O ile wcześniej badacze Teatru Reduty i Teatru Rapsodycznego podkreślali fundamentalne znaczenie słowa w obu koncepcjach, słowa rozumianego w kontekście praelementów teatru, przypisując mu szczególne wartości kreacyjne i sakralne, o tyle dopiero zestawienie najważniejszych fragmentów, cytatów, listów oraz rozważań Kotlarczyka, Wojtyły i Osterwy, ukazuje skalę zbieżności obu koncepcji.

Badając siłę oddziaływania idei Teatru Rapsodycznego we współczesnym teatrze, Katarzyna Flader pisze o promieniowaniu rapsodyzmu, które to zjawisko łączy z procesem "niezwykłego” oddziaływania mowy na odbiorcę oraz z badaniami z zakresu antropologii i filozofii języka, a także z teologią teatru (Flader, Promieniowanie rapsodyzmu 11). To drugie zjawisko wydaje się szczególnie interesujące, bo jak zauważa Flader:

Teatr, poszukując odpowiedzi dotyczących najważniejszych, bo egzystencjalnych zagadnień: sensu życia, celowości cierpienia, miłości, staje się niekiedy bliski teologii. Podejmując problemy eschatologiczne, przedstawiając byt w świetle zagadnień ostatecznych, wchodzi - bardziej lub mniej świadomie - w relację z nauką o Bogu. Między innymi dlatego w badaniach nad sztuką sceniczną znajduje się miejsce na dialog teatru z teologią. („Juliusza Osterwy teologia teatru”)

Wydaje się zatem uzasadnione stwierdzenie, że na płaszczyźnie teologii teatru możliwe okazało się spotkanie koncepcji słowa Wojtyły i Osterwy. Spotkanie o tyle ciekawe, że przekraczające zwykłą li tylko możliwość posługiwania się kategoriami i pojęciami teologicznymi dla nazywania zjawisk teatralnych ${ }^{8}$. Obaj twórcy byli bowiem głęboko przekonani o zdolności kreacyjnej Słowa (pisanego wielką literą). Osterwie nie udało się zrealizować zamierzeń Dali i Genezji. Inaczej potoczyły się losy Karola Wojtyły - papieża Jana Pawła II, który, porzucając sztukę aktorską słowa żywego, przez całe życie i w inny sposób służył Słowu.

\section{BIBLIOGRAFIA}

Ciechowicz, Jan. „Reduta słowa. Dogmat i świętość w Teatrze Rapsodycznym”. Dramat i teatr religijny w Polsce, red. Irena Sławińska i Wojciech Kaczmarek, Towarzystwo Naukowe Katolickiego Uniwersytetu Lubelskiego, 1991, ss. 387-400.

Ciechowicz, Jan. „Światopogląd teatralny Karola Wojtyły”. Jan Ciechowicz. Dom opowieści. Ze studiów nad Teatrem Rapsodycznym Mieczysława Kotlarczyka. Wydawnictwo Uniwersytetu Gdańskiego, 1992, ss. 114-128.

\footnotetext{
${ }^{8} \mathrm{~W}$ artykule zatytułowanym Juliusza Osterwy teologia teatru. Szkic Flader analizuje podstawowe pojęcia doktryny teatralnej Osterwy w kontekście pojęć teologicznych, określając twórcę Reduty „teologiem teatru w działaniu” (zob. Flader, „Juliusza Osterwy teologia teatru”).
} 
Ciechowicz, Jan. „Z Wadowic w świat. Karol Wojtyła i teatr”. Pamiętnik Teatralny, nr 1-2, 2005, ss. 7-15.

Flader, Katarzyna. „Juliusza Osterwy teologia teatru. Szkic”. Performer, nr 3, 2011, www.grotowski. net/performer/performer-3/juliusza-osterwy-teologia-teatru-szkic. Dostęp 10.11.2020.

Flader, Katarzyna. Promieniowanie rapsodyzmu. W kręgu myśli i praktyki teatralnej Mieczysława Kotlarczyka. Wydawnictwo Uniwersytetu Kardynała Stefana Wyszyńskiego, 2008.

Kosiński, Dariusz. „Żywosłowie”. Performer, nr 3, 2011, www.grotowski.net/performer/performer-3/ zywoslowie. Dostęp 10.11.2020.

Kotlarczyk, Mieczysław. „Teatr Nasz”. Mieczysław Kotlarczyk i Karol Wojtyła. O Teatrze Rapsodycznym. 60-lecie powstania Teatru Rapsodycznego. Wstęp i oprac. Jacek Popiel, wybór tekstów Tadeusz Malak i Jacek Popiel, Państwowa Wyższa Szkoła Teatralna im. Ludwika Solskiego w Krakowie, 2001, 3-10.

Kotlarczyk, Mieczysław. „Co to jest teatr Rapsodyczny?”. Mieczysław Kotlarczyk i Karol Wojtyła. O Teatrze Rapsodycznym. 60-lecie powstania Teatru Rapsodycznego. Wstęp i oprac. Jacek Popiel, wybór tekstów Tadeusz Malak i Jacek Popiel, Państwowa Wyższa Szkoła Teatralna im. Ludwika Solskiego w Krakowie, 2001, ss. 11-12.

Kotlarczyk, Mieczysław, i Karol Wojtyła. O Teatrze Rapsodycznym. 60-lecie powstania Teatru Rapsodycznego. Wstęp i oprac. Jacek Popiel, wybór tekstów Tadeusz Malak i Jacek Popiel, Państwowa Wyższa Szkoła Teatralna im. Ludwika Solskiego w Krakowie, 2001.

Osiński, Zbigniew. „Przypomnienie Genezji Juliusza Osterwy”. Etos życia-etos sztuki. Wokół legendy $o$ św. Genezjuszu - aktorze, red. Małgorzata Leyko i Irena Jajte-Lewkowicz, Wydawnictwo Uniwersytetu Łódzkiego, 2005, ss. 139-163.

Osterwa, Juliusz. Przez teatr - poza teatr. Wybór i oprac. Ireneusz Guszpit i Dariusz Kosiński, Towarzystwo Naukowe Societas Vistula, 2004.

Pasierb, Janusz, Stanisław. „Poezja uniwersaliów”. Znak, nr 4-5, 1981, s. 592.

Popiel, Jacek. „Teatr w biografii Karola Wojtyły”. Jacek Popiel. Los artysty w czasach zniewolenia. Teatr Rapsodyczny 1941-1967. Wydawnictwo Uniwersytetu Jagiellońskiego, ss. 247-292.

Sobiecka, Anna. „Kudliński i Osterwa. Sprawa Hamleta”. Annales Universitatis Paedagogicae Cracoviensis. Studia Historicolitteraria, nr 18, folia 263, 2018, ss. 139-151.

Świątkowska, Wanda. Ksiązę Hamlet Juliusza Osterwy. Księgarnia Akademicka, 2009.

Teatr Rapsodyczny. Zakład Doskonalenia Rzemiosła w Krakowie, 1948.

Wojtyła, Karol [Piotr Jasień]. „O teatrze słowa”. Poezje i dramaty. Wybór i układ Marek Skwarnicki i Jerzy Turowicz, Znak, 2001, ss. 435-442.

Wojtyła, Karol [Andrzej Jawień]. „Dramat słowa i gestu”. Poezje i dramaty. Wybór i układ Marek Skwarnicki i Jerzy Turowicz, Znak, 2001, ss. 443-447.

Wojtyła, Karol. Dzieła literackie i teatralne, t. 1: Juwenilia (1938-1946), red. Jacek Popiel i in., Znak, 2019.

Wojtyła, Karol. Poezje i dramaty. Wybór i układ Marek Skwarnicki i Jerzy Turowicz, Znak, 2001.

\section{TEATR SŁOWA. \\ WOKÓ£ KONCEPCJI JULIUSZA OSTERWY ORAZ MIECZYSŁAWA KOTLARCZYKA I KAROLA WOJTYŁY}

Streszczenie

Artykuł prezentuje dwie teorie teatru słowa Juliusza Osterwy oraz Mieczysława Kotlarczyka i Karola Wojtyły. W rozumieniu twórców przynależą one do zjawiska określonego mianem ,praelementów teatru”. Stanowisko to wydaje się o tyle interesujące, że zdaniem Jana Ciechowicza stanowi podstawę „światopoglądu teatralnego” Wojtyły, zaś w ocenie Janusza Pasierba „korzenie metodologiczne” jego 
poetyki i dramaturgii. Zaprezentowane analizy obejmują kanoniczne teksty obu twórców: listy i zapiski prywatne Osterwy zgromadzone w tomie Przez teatr - poza teatr (2004) oraz korespondencję, publicystykę teatralną i wypowiedzi teoretycznoteatralne Wojtyły opublikowane w wyborze Poezje $i$ dramaty (2001) i przypomniane niedawno w jego Dziełach literackich i teatralnych (2019). Słowo rozumiane jako „praelement teatru”, a zarazem jako siła żywa i działająca, stanowi - w moim rozumieniu - podstawowy wyznacznik myślenia teatrem Karola Wojtyły.

Słowa kluczowe: Karol Wojtyła; Mieczysław Kotlarczyk; Juliusz Osterwa; teatr słowa; teologia teatru

THE THEATRE OF THE WORD.

THE CONCEPTS OF JULIUSZ OSTERWA, MIECZYSŁAW KOTLARCZYK, AND KAROL WOJTYŁA

Sum mary

The purpose of this article is to present two different theories about the "theatre of the word," the first of these theories held by Juliusz Osterwa, and the second one held by Mieczysław Kotlarczyk and Karol Wojtyła. The idea that these theories belong to the literary phenomenon termed "proto-elements of theatre" is shared by all three of these conceptual authors. This phenomenon seems to be especially interesting because, according to Jan Ciechowicz, it constitutes the basis of Karol Wojtyła's "theatrical world-view," and, according to Janusz Pasierb, it also forms the "methodological roots" of Wojtyła's poetry and drama. The analyses of the phenomenon presented in this article cover the canonical texts of both authors: the letters and private writings of Osterwa, gathered in the tome Przez teatr - poza teatr (2004), as well as Wojtyła's correspondence, journalistic writings concerning the theatre and his works dealing with the theory of theatre, published in Poezje $i$ dramaty (2001), and recalled in the recent Dzieła literackie i teatralne (2019). The spoken word, understood as a "proto-element of theatre," and, at the same time, as a working, living force, is - in my understanding - a basic tenet of Karol Wojtyła's thinking about theatre.

Keywords: Karol Wojtyła; Mieczysław Kotlarczyk; Juliusz Osterwa; "theatre of the word"; theology of theatre 